\title{
AUDIT TI PADA PT SINAR ACEH MENGGUNAKAN FRAMEWORK COBIT 4.1
}

\author{
IT Audit at PT. Sinar Aceh Using Cobit 4.1 \\ Johanes Fernandes Andry ${ }^{1)}$, Rengga Eko Riwanto ${ }^{2)}$ \\ 1),2) Program Studi Sistem Informasi, Universitas Bunda Mulia, Jakarta \\ Diterima 5 Januari 2019 / Disetujui 19 Februari 2019
}

\begin{abstract}
PT Sinar Aceh is company engaged in the garment, especially underwear, using IT to integrate between various internal divisions and branches and head office to meet the needs and business goals, Implement IT governance by COBIT. Evaluation is done to the internal performance of IT division, so as to improve performance in achieving the business objectives of the company. The focus of the study was conducted on the ME domain. Audit results are appropriate recommendations for IT governance in companies in accordance with COBIT framework 4.1. Found that the level of maturity of IT Governance at the Company on the level of 0.85. This means there is evidence that company has acknowledged that there is a problem and needs to be addressed. However, there is no standard process. Overall approach to irregular management. The current level of maturity is below the expected maturity level, so it needs to be fixed at the expected level. To overcome the existing gap has been recommended several steps that must be done.
\end{abstract}

\section{Keywords: Audit, PT Sinar Aceh, COBIT, ME}

\begin{abstract}
Abstrak
PT Sinar Aceh adalah perusahaan yang bergerak di bidang garmen, khususnya underwear, menggunakan TI untuk mengintegrasikan antara berbagai divisi intern dan cabang dengan pusat untuk memenuhi kebutuhan dan tujuan bisnis perusahaan. Evaluasi tata kelola teknologi informasi menggunakan COBIT. Evaluasi dilakukan terhadap kinerja intern divisi TI, sehingga dapat meningkatkan kinerja dalam mencapai tujuan bisnis perusahaan. Fokus penelitian dilakukan pada domain ME. Hasil dari audit ini adalah rekomendasi yang tepat untuk tata kelola TI pada perusahaan sesuai dengan COBIT framework 4.1. Hasil penelitian ditemukan bahwa tingkat kematangan Tata Kelola TI pada Perusahaan pada level 0.85. Artinya ada bukti bahwa perusahaan telah mengakui bahwa ada masalah dan perlu ditangani. Namun demikian, tidak ada proses standar. Pendekatan keseluruhan untuk manajemen tidak teratur. Tingkat kematangan yang ada saat ini berada di bawah tingkat kematangan yang diharapkan, sehingga perlu diperbaiki di level yang diharapkan. Untuk mengatasi gap yang ada telah direkomendasikan beberapa langkah yang harus dilakukan.
\end{abstract}

Kata Kunci : Audit, PT Sinar Aceh, COBIT, ME

\section{Pendahuluan}

Keterlibatan Teknologi Informasi (TI) dalam suatu perusahaan memerlukan biaya yang besar dan memungkinkan terjadinya resiko kegagalan yang cukup tinggi. Di sisi lain penerapan TI juga dapat memberikan keuntungan dengan menyediakan peluang-peluang untuk meningkatkan produktifitas bisnis yang sedang berjalan. Pengelolaan TI untuk PT Sinar Aceh dilakukan pada domain ME. Pemilihan domain

*Korespondesi Penulis:

E-mail: jandry@bundamulia.ac.id tersebut disesuaikan dengan permasalahan dan kebutuhan Perusahaan dalam melakukan pengelolaan TI, mencakup penyampaian dan dukungan layanan TI dapat berjalan maksimal.

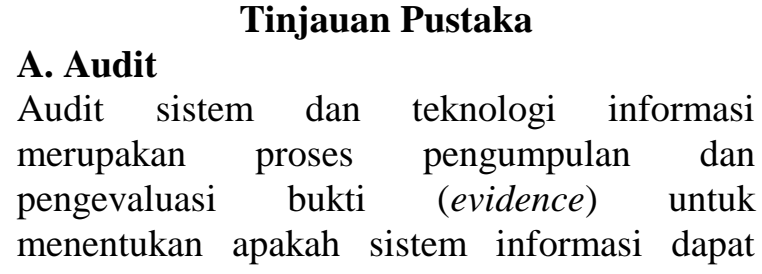


melindungi aset dan teknologi informasi yang ada telah memelihara integritas data sehingga keduanya dapat diarahkan pada pencapaian tujuan bisnis secara efektif dengan menggunakan sumber daya secara efektif dan efisien (Sarno, 2009), (Rozas, 2012).

\section{B. Tata Kelola TI}

Tata kelola TI didefinisikan sebagai tanggungjawab eksekutif dan dewan direktur, dan terdiri atas kepemimpinan, struktur organisasi serta proses-proses yang memastikan TI perusahaan mendukung dan memperluas obyektif dan strategi organisasi (Juliandarini, 2013). Tujuan tata kelola TI adalah agar dapat mengarahkan upaya TI, sehingga memastikan performa TI sesuai dengan pemenuhan obyektif (Surendro, 2009), (Muthmainnah, 2015). Tata kelola TI membutuhkan pengaturan yang tepat untuk memadukan strategi TI dan pemanfaatan sumber daya TI guna memberikan keuntungan yang kompetitif bagi organisasi. sederhananya, tata kelola TI menggunakan prinsip-prinsip tata kelola organisasi terhadap unit TI (Amroni, 2011).

\section{COBIT 4.1}

COBIT (Control Objectives for Information and Related Technology) adalah standar untuk informasi dan teknologi yang menyertainya yang berlaku internasional. Sebagai sebuah framework yang mengatur pengelolaan informasi, COBIT memiliku standar pengelolaan informasi yang terbagi dalam 4 domain, yaitu: Plan and Organize (PO), Acquire and Implement (AI), Delivery and Support (DS), dan Monitoring and Evaluate (ME)" (Carolina, 2015), (IT Governance Institute, 2007).

COBIT mendefiniskan Control objective IT sebagai pernyataan mengenai hasil atau tujuan yang harus dicapai melalui penerapan prosedur kendali dalam aktivitas TI tertentu. Pada edisi keempat ini COBIT framework terdiri dari 34 high level control objectives dikelompokkan dalam 4 domain utama, bisa dilihat pada Gambar 1. Framework COBIT (Surbakti, 2012), (IT Governance Institute, 2007):

1. Planning \& Organisation, Domain ini menitikberatkan pada proses perencanaan dan penyelarasan strategi TI dengan strategi perusahaan.
2. Acquisition \& Implementation, Domain ini menitikberatkan pada proses pemilihan, pengadaaan dan penerapan teknologi informasi yang digunakan.

3. Delivery \& Support, Domain ini menitikberatkan pada proses pelayanan TI dan dukungan teknisnya.

4. Monitoring, Domain ini menitikberatkan pada proses pengawasan pengelolaan TI pada organisasi.

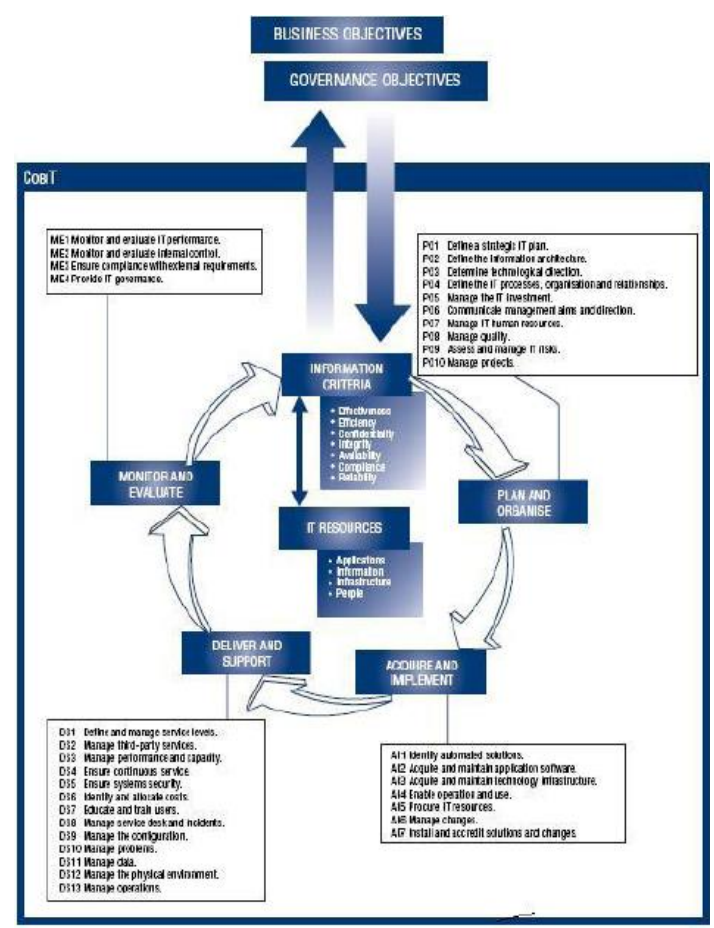

Gambar 1. Framework COBIT (IT Governance Institute) (Surbakti, 2012), (IT Governance

Institute, 2007), (Andry 2016), (Andry, 2018)

\section{Maturity Level}

Maturity Level atau tingkat kematangan membantu menentukan tahapan dan level ekspetasi dari control serta membandingkannya dengan standar yang ada.

Level 0 Non-existent - tidak ada sama sekali proses yang terlihat. Perusahaan belum menyadari bahwa ada masalah yang harus dikaji.

Level 1 Initial/Ad Hoc - Ada bukti bahwa perusahaan telah menyadari ada masalah yang ada dan harus dikaji namun belum ada standarisasi. Tetapi, ada pendekatan ad hoc yang cenderung diaplikasikan sesuai kasus. Pendakatan manajemen secara umum tidak terstruktur. 
Level 2 Repeatable but Intuitive - Proses telah dikembangkan pada tahap dimana prosedur yang mirip telah diikuti oleh bermacam-macam orang yang melaksanakan tugas ini. Tidak ada training atau komunikasi secara formal tentang prosedur standard dan tanggung jawabnya jatuh pada individu. Ada ketergantungan yang tinggi pada individu dan sering terjadi error.

Level 3 Defined Process - Prosedur telah terstandarisasi dan terdokumentasi, dan komunikasi lewat training. Merupakan keharusan bahwa proses tersebut harus diikuti. Tetapi, sedikit deviasi yang terjadi. Prosedur tersebut tidak rumit tetapi formalisasi dari practice yang sekarang

Level 4 Managed and measurable manajemen memantau dan mengukur kesesuaian dengan prosedur dan mengambil tindakan dimana proses terlihat tidak berjalan efektif. Proses dikembangkan secara berkelanjutan dan memberikan practice yang baik. Otomasi dan alat bantu digunakan dalam cara yang terbatas dan terpecah-pecah.

Level 5 Optimised - proses telah dirancang sampai tingkat pelaksanaan yang baik, berdasarkan hasil dari pengembangan berkelanjutan dan maturity modelling dengan perusahaan lain. TI digunakan dalam cara terintegrasi untuk mengotomasikan alur kerja, menyediakan alat bantu untuk meningkatkan kualitas dan efektivitas, membuat perusahaan mudah diadaptasi (IT Governance Institute, 2007), (Andry, 2016)

\section{Metode Penelitian}

tahapan penulis dalam mengambil ataupun memperoleh data dari sumber, mulai dari survei awal, wawancara dan kuisioner ditujukan pada Gambar 2. Diagram Alir Penelitian.

Prosedur Penelitian merupakan suatu kegiatan yang harus dilakukan dalam melakukan penelitian. Adapun tahapan dan prosedur penelitiannya sebagai berikut (Jelvino, 2017):

1) Planning (Perencanaan), merupakan tahapan awal dalam prosedur penelitian dilakukan. Karena pada tahap ini penulis dapat menentukan ruang lingkup (scope), sebuah objek di audit, standar evaluasi dari hasil audit serta komunikasi terhadap orang yang bersangkutan akan organisasi/perusahaan yang akan diaudit dengan menganalisa visi, misi, sasaran dan tujuan objek, dan yang terkait dengan pengolahan investigasi. Pada tahap perancangan meliputi beberapa aktifitas utama yaitu penetapan ruang lingkup dan tujuan audit, pengorganisasian tim audit, pemahaman mengenai operasi bisnis klien, pengkajian ulang hasil audit sebelumnya, dan penyiapan prosedur audit.

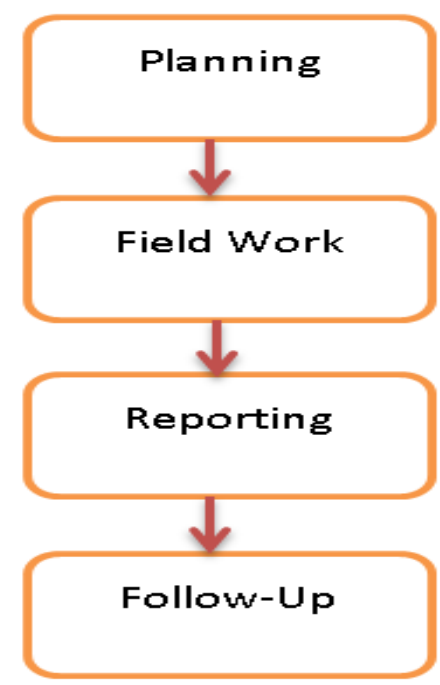

Gambar 2. Diagram Alir Penelitian

2) Field Work (Pemeriksaan Lapangan), Pada tahap ini penulis ingin mendapatkan informasi dengan cara mengumpulkan data-data dari stakeholder yang terkait yang menggunakan beberapa metode yang dapat dilakukan seperti; wawancara, kuesioner, dan dilakukan survey ke tempat perusahaan. Data yang di dapat akan sangat berguna dalam membantu penulis melakukan analisa sebuah institusi yang di audit.

3)Reporting (Pelaporan), Setelah proses pengumpulan data-data dari perusahaan, maka akan data tersebut yang akan diproses untuk dihitung berdasarkan maturity levelnya. Pada tahap ini yang akan dilakukan penulis memberikan informasi berupa hasil-hasil dari audit yang dilakukan. Perhitungan maturity level dilakukan berpedoman pada hasil wawancara, survey dan rekapitulasi hasil penyebaran kuesioner. Berdasarkan hasil maturity level yang mencerminkan kinerja saat ini dan kinerja ideal yang diharapkan akan menjadi acuan untuk selanjutnya dilakukan analisis kesenjangan (gap). Hal tersebut dimaksudkan untuk mengetahui kesenjangan serta mengetahui apa yang menyebabkan adanya kesenjangan tersebut. Dengan adanya 
pelaporan maka suatu masalah akan dapat terlihat lebih jelas dimana letak yang harus diperbaiki.

4) Follow-Up (Tindak Lanjut), Setelah dilakukan pelaporan atau reporting maka hal yang dilakukan selanjutnya adalah memberikan laporan hasil audit berupa rekomendasi atau koreksi tindakan perbaikan kepada pihak managemen, untuk selanjutnya wewenang perbaikan menjadi tanggung jawab managemen, apakah akan diterapkan atau hanya menjadi acuhan untuk perbaikan dimasa yang akan datang.

\section{Hasil dan Pembahasan}

Pembahasan dibagi menjadi 8 point, point 1 s/d 4 adalah hasil audit tingkat kematangan domain ME, point 5 adalah rangkuman dari tingkat kematangan, point 6 adalah kesenjangan, point 7 adalah temuan masalah dan rekomendaasi dan point 8 adalah rangkuman temuan masalah dan rekomendasi.

1. ME1 Monitor and Evaluate IT Performance

Manajemen IT performance yang efektif membutuhkan proses monitoring. Proses ini meliputi penentuan indikator kinerja yang relevan, pelaporan yang sistematis dan kinerja yang tepat waktu, dan bertindak cepat dalam menangani penyimpangan yang muncul. Pemantauan diperlukan untuk memastikan bahwa hal yang benar dilakukan dan sejalan dengan arah yang telah di set dan kebijakan yang ada. Hasil perhitungan dari sub domain ME1 adalah seperti ditampilkan pada Tabel 1 . Maturity Level ME1.

Tabel 1. Maturity Level ME1

\begin{tabular}{|c|l|c|}
\hline Domain & \multicolumn{1}{|c|}{ Keterangan } & Level \\
\hline ME 1.1 & Monitoring Approach & 1 \\
\hline ME 1.2 & $\begin{array}{l}\text { Definitions and Collection of } \\
\text { Monitoring Data }\end{array}$ & 1 \\
\hline ME 1.3 & Monitoring Method & 1 \\
\hline ME 1.4 & Performance Assessment & 1 \\
\hline ME 1.5 & Board and Executive Reporting & 2 \\
\hline ME 1.6 & Remedial Actions & 1 \\
\hline & Rata-rata & 1.17 \\
\hline
\end{tabular}

\section{ME2 Monitor and Evaluate Internal Control}

Menetapkan program pengendalian internal yang efektif untuk TI, membutuhkan proses monitoring yang jelas. Proses ini meliputi monitoring dan pelaporan pengecualian yang ada di kontrol internal, hasil review dari selfassessments dan review dari pihak ketiga.

Tabel 2. Maturity Level ME2

\begin{tabular}{|l|l|c|}
\hline Domain & Keterangan & Level \\
\hline ME 2.1 & $\begin{array}{l}\text { Monitoring of Internal Control } \\
\text { Framework }\end{array}$ & 2 \\
\hline ME 2.2 & Supervisory Review & 2 \\
\hline ME 2.3 & Control Exceptions & 1 \\
\hline ME 2.4 & Control Self-assessment & 0 \\
\hline ME 2.5 & Assurance of Internal Control & 1 \\
\hline ME 2.6 & $\begin{array}{l}\text { Internal Co n trol at } \\
\text { Third P a rt i e s }\end{array}$ & 2 \\
\hline ME 2.7 & Remedial Actions & 2 \\
\hline & Rata-rata & 1.43 \\
\hline
\end{tabular}

Manfaat utama dari monitoring pengendalian internal adalah untuk memberikan jaminan mengenai operasi dan kepatuhan terhadap hukum dan peraturan yang berlaku efektif dan efisien. Hasil perhitungan dari domain ME2 adalah seperti ditampilkan pada Tabel 2 Maturity Level ME2.

\section{ME3 Ensure Compliance With External Requirements}

Pengawasan compliance yang efektif memerlukan pembentukan proses review untuk memastikan kepatuhan terhadap hukum, peraturan dan persyaratan kontrak. Proses ini meliputi identifikasi persyaratan compliance, mengoptimalkan dan mengevaluasi respon, memperoleh jaminan bahwa persyaratan telah dipenuhi dan, akhirnya, mengintegrasikan laporan IT compliance dari sisa bisnis lainnya. Hasil perhitungan dari domain ME3 adalah seperti ditampilkan pada Tabel 3 Maturity Level ME3.

Tabel 3. Maturity Level ME3

\begin{tabular}{|c|l|c|}
\hline Domain & \multicolumn{1}{|c|}{ Keterangan } & Level \\
\hline ME 3.1 & $\begin{array}{l}\text { Identification of External } \\
\text { Legal, Regulatory }\end{array}$ & 0 \\
\hline ME 3.2 & $\begin{array}{l}\text { Optimisation of Response to } \\
\text { External Requirements }\end{array}$ & 1 \\
\hline ME 3.3 & $\begin{array}{l}\text { Evaluation of Compliance } \\
\text { With External Requirements }\end{array}$ & 1 \\
\hline ME 3.4 & $\begin{array}{l}\text { Positive Assurance of } \\
\text { Compliance }\end{array}$ & 1 \\
\hline ME 3.5 & Integrated Reporting & 1 \\
\hline & R a t a - r a t a & 0.8 \\
\hline
\end{tabular}

\section{ME4 Provide IT Governance}

Membangun kerangka (framework) kerja tata kelola yang efektif termasuk mendefinisikan struktur, proses, kepemimpinan, peran dan tanggung jawab organisasi untuk memastikan bahwa perusahaan IT investasi sejalan dan juga disampaikan sesuai dengan strategi dan tujuan perusahaan. Hasil perhitungan dari domain 
ME4 adalah seperti ditampilkan pada Tabel 4 Maturity Level ME4.

Tabel 4 Maturity Level ME 4

\begin{tabular}{|c|l|c|}
\hline Domain & \multicolumn{1}{|c|}{ Keterangan } & Level \\
\hline ME 4.1 & $\begin{array}{l}\text { Establishment of an IT } \\
\text { Governance Framework }\end{array}$ & 2 \\
\hline ME 4.2 & Strategic Alignment & 2 \\
\hline ME 4.3 & Value Delivery & 3 \\
\hline ME 4.4 & Resource Management & 2 \\
\hline ME 4.5 & Risk Management & 1 \\
\hline ME 4.6 & $\begin{array}{l}\text { Performance } \\
\text { Me a s u re ment }\end{array}$ & 2 \\
\hline ME 4.7 & Independent Assurance & 1 \\
\hline & Rata-rata & 1.86 \\
\hline
\end{tabular}

\section{Rangkuman Tingkat Kematangan}

Berikut rangkuman dari tingkat kematangan (Maturity Level) ditampilkan pada Tabel 5 Rangkuman Tingkat Kematangan.

Hasil perhitungan mendapati rata-rata nilai domain tata kelola teknologi informasi pada PT Sinar Aceh sebesar 1.56. Dari nilai ini dapat tarik kesimpulan bahwa pengelolaan teknologi informasi dilakukan secara Intial/AdHoc artinya pada level ini, Ada bukti bahwa perusahaan telah mengakui bahwa masalah ada dan perlu ditangani. Ada, namun tidak ada proses standar; sebaliknya, ada pendekatan ad hoc yang cenderung diterapkan pada individu atau berdasarkan kasus per kasus. Keseluruhan pendekatan manajemen tidak teratur.

Tabel 5. Rangkuman Tingkat Kematangan

\begin{tabular}{|c|l|c|c|}
\hline Domain & \multicolumn{1}{|c|}{ Keterangan } & Nilai & Kondisi \\
\hline ME1 & $\begin{array}{l}\text { Monitor and } \\
\text { Evaluate IT } \\
\text { Performance }\end{array}$ & 1.17 & $\begin{array}{c}\text { Intial/Ad } \\
\text { Hoc }\end{array}$ \\
\hline ME2 & $\begin{array}{l}\text { Monitor and } \\
\text { Evaluate } \\
\text { Internal Control }\end{array}$ & 1.43 & $\begin{array}{c}\text { Intial/Ad } \\
\text { Hoc }\end{array}$ \\
\hline ME3 & $\begin{array}{l}\text { Ensure } \\
\text { Compliance With } \\
\text { External } \\
\text { Requirements }\end{array}$ & 0.8 & $\begin{array}{c}\text { Non- } \\
\text { Existent }\end{array}$ \\
\hline ME4 & $\begin{array}{l}\text { Provide IT } \\
\text { Governance }\end{array}$ & 1.86 & $\begin{array}{c}\text { Intial/Ad } \\
\text { Hoc }\end{array}$ \\
\hline & Rata-rata & $\mathbf{0 . 8 5}$ & $\begin{array}{c}\text { Non- } \\
\text { Existent }\end{array}$ \\
\hline
\end{tabular}

Tata kelola pada PT Sinar Aceh memiliki expected level 2 Repeatable but Intuitive, proses telah dikembangkan untuk tahap dimana prosedur yang sama diikuti oleh orang yang berbeda melaksanakan tugas yang sama. Tidak ada pelatihan formal atau komunikasi dari prosedur standar, dan tanggung jawab yang tersisa untuk individu. Ada yang tinggi tingkat ketergantungan pada pengetahuan individu dan, oleh karena itu, kesalahan mungkin terjadi. Sangat dibutuhkan proses-proses ini digunakan untuk membantu manejer, ketua tim dan anggota tim pengembangan sehingga bekerja dengan lebih efektif.

\section{Nilai Kesenjangan (GAP)}

Setelah menilai dan mengetaui tingkat kematangan tata kelola saat ini sebesar 1.56, maka dilakukan analisis kesenjangan terhadap tingkat kematangan yang diharapkan yaitu sebesar 2. Alasan level yang ingin dicapai sebesar 2 adalah kesiapan PT Sinar Aceh dalam bidang TI, Pengelolaan SDM, Manajemen, dan Keuangan. Tabel dibawah ini menunjukan gap antara tingkat kematangan saat ini dengan tingkat kematangan yang diharapkan. Tabel 6 Tingkat Kesenjangan, memperlihatkan GAP antara Current dan Expected Level.

Tabel 6. Tingkat Kesenjangan (GAP)

\begin{tabular}{|c|c|c|c|}
\hline Domain & \multicolumn{3}{|c|}{ Tingkat Kematangan } \\
\hline \multirow{2}{*}{ ME } & Saat Ini & Diharapkan & $\begin{array}{c}\text { Gap (Diharapkan } \\
\text { saat ini) }\end{array}$ \\
\cline { 2 - 4 } & 0,85 & 2 & $2-0,85$ \\
\hline \multicolumn{3}{|c|}{ Rata-rata } & 1,15 \\
\hline
\end{tabular}

Terdapat jarak 1.15 pada domain ME, antara kondisi yang diharapkan dengan kondisi saat ini. Walaupun gap terbilang kecil tetapi dibutuhkan penyesuaian masing-masing domain karena nilai adalah nilai rata-rata perdomain, maka penulis akan tetap akan memberikan rekomendasi pada masing masing sub domain sehingga perbaikan lebih fokus pada bagian domain yang lemah.

\section{Temuan Masalah dan Rekomendasi}

Berikut temuan masalah dan rekomendasi terhadap masing-masing domain ME.

\subsection{ME1 Monitor and Evaluate IT Performance}

Pada ME1 masih tergolong Intial/Ad Hoc (1.17), proses telah dikembangkan untuk tahap dimana prosedur yang sama diikuti oleh orang yang berbeda melaksanakan tugas yang sama. Tidak ada pelatihan formal atau komunikasi dari prosedur standar, dan tanggung jawab yang 
tersisa untuk individu. Ada yang tinggi tingkat ketergantungan pada pengetahuan individu dan, oleh karena itu, kesalahan mungkin terjadi.

\subsubsection{Temuan Masalah pada ME1}

Belum adanya kerangka pemantauan umum kinerja kerja. Selama ini hanya berdasarkan masalah yang ditemukan, lalu diselesaikan dan hasilnya nanti apakah user merasa puas atau tidak.

a) Belum adanya metodologi untuk TI Solution. Hanya berdasarkan masalah yang ditemukan dan diselesaikan bersama.

b) Tidak ada tolok ukur untuk membandingkan dengan target. Hanya berdasarkan masalah yang ditemukan dan diselesaikan dengan formula yang baru.

c) Tidak adanya jadwal berkala untuk meninjau kinerja terhadap target khusunya dibagian IT.

d) Belum adanya analisis khusus untuk memastikan adanya penyimpangan.

\subsubsection{Rekomendasi untuk ME1}

a) Segera dibentuk pemantauan umum kinerja kerja, sehingga dapat meningkatkan efektif dan efisien alur dalam divisi TI.

b) Perlu adanya metodologi untuk IT Solution, lebih baik untuk tidak menunggu masalah dari user. Divisi TI harus bisa memonitor apakah terdapat masalah diberbagai divisi lainnya.

c) Perlu adanya studi banding ke perusahaan TI lainnya, walaupun hanya sebatas TI yang mensupport perusahaan. Setelah adanya studi banding tersebut pastinya TI akan termotivasi untuk maju dan dapat lebih efektif dalam pengoperasiannya.

d) Analisi khusus sangatlah dibutuhkan dalam penanganan masalah, supaya akar penyebab masalah dapat ditemukan dan tidak terjatuh di lubang yang sama.

\subsection{ME2 Monitor and Evaluate Internal} Control

Pada ME2 masih tergolong Intial/Ad Hoc (1.43), ada bukti bahwa perusahaan telah mengakui bahwa masalah ada dan perlu ditangani. Ada, namun tidak ada proses standar; sebaliknya, ada pendekatan ad hoc yang cenderung diterapkan pada individu atau berdasarkan kasus per kasus. Keseluruhan pendekatan manajemen tidak teratur.

\subsubsection{Temuan Masalah pada ME2}

a) Belum adanya pemantauan dan pengevaluasian efisiensi dan efektivitas IT internal sesuai dengan yang ditetapkan oleh manajerial control.

b) Tidak tersedianya dana sehingga lembaga korektif untuk divisi TI tidak ada, sedangkan lembaga tersebut dibutuhkan dan harus dikomuikasikan dulu kepada manajemen.

c) Belum ada report dalam pengendalian TI, karena membutuhkan modal yang fokus.

d) Semua tindakan perbaikan berdasarkan masalah yang diterima dari user.

\subsubsection{Rekomendasi untuk ME2}

a) Segera dibentuk team pemantauan dan pengevaluasian efesiensi dan efektivitas TI internal seseuai yang ditetapkan manajerial kontrol. Jika belum dibentuk manajerial kontrolnya harus segera dibentuk terlebih dahulu, karena menyangkut dengan efektivitas perusahaan dan perlu juga persetujuan dari berbagai divisi lainnya.

b) Jika tidak terdapat dana/modal yang cukup maka dapat dibentuk team khusus dalam divisi TI yang bertugas untuk korektif dengan jadwal berkala sehingga dapat menjadikannya lebih efektif.

c) Jangan hanya berpatok dari masalah yang disampaikan oleh user, divisi TI harus terus mendalami sistem yang mereka buat sehingga dapat menemukan kelemahannya.

\subsection{ME3 Ensure Compliance With External} Requirements

Pada ME3 masih tergolong Non-Existent (0.8), kurangnya lengkap dari setiap proses dikenali. perusahaan telah bahkan tidak mengakui bahwa ada masalah yang harus ditangani.

\subsubsection{Temuan Masalah Pada ME3}

a) Tidak ada hukum local/internasional, persyaratan, dan peraturan lain yang diselaraskan untuk divisi TI.

b) Karena semua kesalahan diselesaikan secara kekeluargaan. 


\subsubsection{Rekomendasi untuk ME3}

a) Karena divisi TI merupakan divisi penting dalam perusahaan, maka perlu diadakannya peraturan, baik berdasarkan intern,local, ataupun internasional.

b) Peraturan yang mengharuskan semua anggota divisi mematuhinya sehingga divisi TI menjadi lebih baik untk kedepannya. Jika terjadi masalah dapat diselesaikan secara kekeluargaan, maka terdapat plus dan minus terhadap divisi tersebut. Plusnya anggota menjadi lebih fleksibel terhadap perkerjaannya, mental rasa ingin tahunya tinggi, dan semakin termotivasi untuk maju, sedangkan minusnya jika terjadi kesalahan maka hanya diselesaikan secara kekeluargaan, tanpa ada hukuman lainnya. Ini menjadikan peraturan tidak kaku dapat menjadikan anggota cenderung dapat mengulangi kesalahannya lagi, walaupun tidak semua anggota.

\subsection{ME4 Provide IT Governance}

Pada ME4 masih tergolong Intial/Ad Hoc (1.86), ada bukti bahwa perusahaan telah mengakui bahwa masalah ada dan perlu ditangani. Ada, namun tidak ada proses standar; sebaliknya, ada pendekatan ad hoc yang cenderung diterapkan pada individu atau berdasarkan kasus per kasus. Keseluruhan pendekatan manajemen tidak teratur.

\subsubsection{Temuan Masalah ME4}

a) Tidak menganut tatakelola di TI Perusahaan dalam pengambilan keputusan. Hanya kepala divisi yang mengambil keputusan yang didorong oleh anggota lainnya.

b) Tidak ada kerja sama dengan komite strategi TI.

c) Belum ada Risk Management, karena masih terfokus dengan kebutuhan saat ini.

d) Belum adanya SOP untuk divisi TI.

\subsubsection{Rekomendasi untuk ME4}

a) Divisi IT tidak menganut tatakelola pengambilan keputusan, hanya kepala divisi yang mengambil keputusan dan didorong oleh anggota lainnya. Selagi kepala divisi dapat bertanggung jawab kepada keputusan yang dibuatnya dan dapat memajukan perusahaannya maka akan baik-baik saja untuk intern perusahaan.

b) Segera dibentuk komite strategi TI dan saling bekerja sama dalam pengoperasiannya sehingga menjadi lebih maju untuk kedepannya.

c) Risk management sangatlah penting, dapat menjadi pembackup jika suatu saat terjadi kesalahan pada sistem. Segera dibentuk seiring pekerjaan lainnya sehingga jika terjadi bencana dapat diantisipasi dengan mudah.

d) Segera bentuk SOP untuk divisi TI, karena strandar pengoperasiannya harus sejalan dengan tujuan bisnis perusahaan.

\section{Rangkuman Temuan dan Rekomendasi}

Hasil evaluasi menunjukan masih terdapat berbagai masalah dalam pengoperasiannya. Antara lain didalam ME1 masih terdapat masalah belum adanya kerangka pemantauan umum, metodologi untuk TI Solution, tolok ukur untuk membandingkan dengan target, jadwal berkala untuk meninjau kinerja terhadap target, dan analisis khusus untuk memastikan adanya penyimpangan. Pada ME2 terdapat masalah belum adanya pemantauan dan pengevaluasian efisiensi dan efektivitas internal IT, tidak tersedianya dana untuk lembaga korektif, report dalam pengendalian TI, perbaikan masalah. Pada ME3 terdapat masalah belum adanya local/internasional persyaratan dan peraturan lain yang diselaraskan dengan divisi TI. Pada ME4 terdapat maslah tentang tidak menganut tatakelola di TI Perusahaan dalam pengambilan keputusan, tidak ada kerja sama dengan komitee TI, belum adanya Risk Management, dan belum adanya SOP divisi TI. Rekomendasi secara umum untuk meingkatkan tata kelola teknologi informasi pada PT Sinar Aceh khususnya dibagian ME adalah peningkatan kepada peforma divisi TI, terutama dalam peningkatan evaluasi kinerja anggota. Pengevaluasian tersebut menyangkut bagaimana anggota bekerja sesuai dengan SOP yang telah ditetapkan, sehingga memiliki tanggung jawab terhadap apa yang telah dikerjakannya. 


\section{Kesimpulan}

PT Sinar Aceh telah menerapkan tata kelola teknologi informasi pada level Intial/Ad Hoc. Hasil audit mendapati rata-rata domain ME sebesar 1.56 dari rentang 0 sampai 5, artinya perusahaan masih belum siap terhadap tata kelola teknologi informasi dengan baik. Ditemukan kelemahan yang terdapat pada domain ME3 dengan nilai rata-rata 0.8 artinya masih pada level non-existent. Level yang paling tinggi pada domain ME1 Monitor and Evaluate IT Performance adalah dengan nilai rata-rata 2.17 artinya kelemahan yang paling fatal adalah tingginya ketergantungan perusahan terhadap satu ahli, risiko tidak dikelola dengan baik, belum melakukan evaluasi terhadap kepuasan mutu, dokumentasi belum dilakukan dibeberapa bidang teknologi informasai, prosedur dan kebijakan belum dilakukan dengan sungguh-sungguh.

\section{Daftar Pustaka}

Amroni, (2011), Analisis tingkat kematangan system informasi perpustakaan STIKES Global Yogyakarta, Tesis, Magister Teknik Informatika, STMIK AMIKOM Yogyakarta.

Andry, J. F., (2016), Audit Sistem Informasi Sumber Daya Manusia Pada Training Center Di Jakarta Menggunakan Framework Cobit 4.1, Jurnal Ilmiah FIFO, vol. VIII, no.1, pp. 28-34, 2016.

Andry, J. F., (2016), Audit Tata Kelola TI Di Perusahaan (Studi Kasus XYZ Cargo), Prosiding Seminar Nasional Teknologi Informasi (SNTI) XIII - 2016, 29 Oktober.

Andry, J. F., Christianto, K., (2018), “Audit Menggunakan Cobit 4.1 Dan Cobit 5 Dengan Case Study", Teknosain, Yogyakarta.

Carolina, I., (2015), Analisa Penilaian Maturity Level Tata Kelola TI Berdasarkan Domain DS Dan ME Menggunakan Cobit 4.1, Seminar Nasional Inovasi dan Tren (SNIT).

IT Governance Institute, (2007), COBIT 4.1 Framework, Control Objective,
Management Guidelines, Maturity Models, Rolling Meadows, IL 60008 USA: ITGI.

Jelvino., Andry, J. F., (2017), Audit Sistem Informasi Absensi pada PT. Bank Central Asia Tbk menggunakan COBIT 4.1, Jurnal Teknik Informatika dan Sistem Informasi, Volume 3 Nomor 2 Agustus 2017

Juliandarini, H, Sri., (2013), Audit Sistem Informasi Pada Digilib Universitas XYZ Menggunakan Kerangka Kerja Cobit 4.0, Jurnal Sarjana Teknik Informatika e-ISSN: 2338-5197, Volume 1 Nomor 1, Juni.

Muthmainnah, (2015), Model Perancangan Tata Kelola Teknologi Informasi (IT Governance) Pada Proses Pengelolaan Data Di Universitas Malikussaleh Lhokseumawe, Techsi Vol. 6 No.1, April.

Rozas, I. S., Effendy, D. A. R., (2012), Mengukur Efektifitas Hasil Audit Teknologi Informasi Cobit 4.1 Berdasarkan Perspektif End User, ISSN 1858-4667 Juranal Link Vol 17/No. 2/September.

Sarno, R., (2009), Strategi Sukses Bisnis dengan Teknologi Informasi Berbasis Balanced Scorecard \& COBIT, ITS Press, Surabaya.

Surbakti, H., (2012), Managing Control Object For IT (Cobit) Sebagai Standar Framework Pada Proses Pengelolaan IT-Governance Dan Audit Sistem Informasi, Vol . VII Nomor 19, Jurnal Teknologi Informasi ISSN : 1907-2430.

Surendro, K., (2009), Implementasi Tata Kelola Teknologi Informasi, Informatika, Bandung. 